University of Nebraska - Lincoln

DigitalCommons@University of Nebraska - Lincoln

\title{
Conversion of switchgrass to ethanol using dilute ammonium hydroxide pretreatment: influence of ecotype and harvest maturity
}

\author{
Bruce S. Dien \\ USDA-ARS National Center for Agricultural Utilization Research, Bruce.Dien@ars.usda.gov \\ Patricia J. O'Bryan \\ USDA-ARS \\ Ronald E. Hector \\ USDA-ARS \\ Loren B. Iten \\ USDA-ARS \\ Robert B. Mitchell \\ University of Nebraska-Lincoln, rob.mitchell@ars.usda.gov \\ See next page for additional authors
}

Follow this and additional works at: https://digitalcommons.unl.edu/usdaarsfacpub

Dien, Bruce S.; O'Bryan, Patricia J.; Hector, Ronald E.; Iten, Loren B.; Mitchell, Robert B.; Qureshi, Nasib; Sarath, Gautum; Vogel, Kenneth P.; and Cotta, Michael A., "Conversion of switchgrass to ethanol using dilute ammonium hydroxide pretreatment: influence of ecotype and harvest maturity" (2013). Publications from USDA-ARS / UNL Faculty. 1948.

https://digitalcommons.unl.edu/usdaarsfacpub/1948

This Article is brought to you for free and open access by the U.S. Department of Agriculture: Agricultural Research Service, Lincoln, Nebraska at DigitalCommons@University of Nebraska - Lincoln. It has been accepted for inclusion in Publications from USDA-ARS / UNL Faculty by an authorized administrator of DigitalCommons@University of Nebraska - Lincoln. 


\section{Authors}

Bruce S. Dien, Patricia J. O'Bryan, Ronald E. Hector, Loren B. Iten, Robert B. Mitchell, Nasib Qureshi, Gautum Sarath, Kenneth P. Vogel, and Michael A. Cotta 
This article was downloaded by: [DigiTop - USDA's Digital Desktop Library]

On: 11 November 2013, At: 09:23

Publisher: Taylor \& Francis

Informa Ltd Registered in England and Wales Registered Number: 1072954 Registered office: Mortimer House, 37-41 Mortimer Street, London W1T 3J H, UK

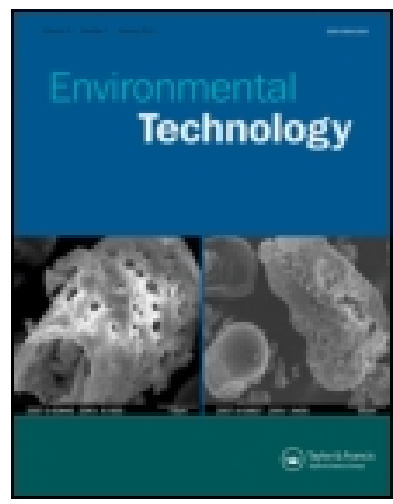

\title{
Environmental Technology
}

Publication details, including instructions for authors and subscription information: http:// www.tandfonline.com/loi/tent20

\section{Conversion of switchgrass to ethanol using dilute ammonium hydroxide pretreatment: influence of ecotype and harvest maturity}

\author{
Bruce S. Dien ${ }^{a}$, Patricia J. O'Bryan ${ }^{a}$, Ronald E. Hector ${ }^{a}$, Loren B. Iten ${ }^{a}$, Robert B. \\ Mitchell ${ }^{b}$, Nasib Qureshi ${ }^{a}$, Gautum Sarath ${ }^{b}$, Kenneth P. Vogel ${ }^{b} \&$ Michael A. Cotta ${ }^{a}$ \\ ${ }^{a}$ Bioenergy Research Unit, National Center for Agricultural Utilization Research, USDA, \\ Agricultural Research Service, 1815 N. University Street, Peoria , IL , 61604-3902, USA \\ ${ }^{\mathrm{b}}$ Grain, Forage, and Bioenergy Research Unit, University of Nebraska, 137 Keim Hall, Box \\ 830937, Lincoln, NE , 68583-0937, USA \\ Published online: 08 Oct 2013.
}

To cite this article: Bruce S. Dien, Patricia J. O'Bryan, Ronald E. Hector, Loren B. Iten, Robert B. Mitchell , Nasib Qureshi , Gautum Sarath, Kenneth P. Vogel \& Michael A. Cotta (2013) Conversion of switchgrass to ethanol using dilute ammonium hydroxide pretreatment: influence of ecotype and harvest maturity, Environmental Technology, 34:13-14, 1837-1848, DOI: $10.1080 / 09593330.2013 .833640$

To link to this article: http:// dx.doi. org/ 10.1080/ 09593330.2013.833640

\section{PLEASE SCROLL DOWN FOR ARTICLE}

Taylor \& Francis makes every effort to ensure the accuracy of all the information (the "Content") contained in the publications on our platform. However, Taylor \& Francis, our agents, and our licensors make no representations or warranties whatsoever as to the accuracy, completeness, or suitability for any purpose of the Content. Any opinions and views expressed in this publication are the opinions and views of the authors, and are not the views of or endorsed by Taylor \& Francis. The accuracy of the Content should not be relied upon and should be independently verified with primary sources of information. Taylor and Francis shall not be liable for any losses, actions, claims, proceedings, demands, costs, expenses, damages, and other liabilities whatsoever or howsoever caused arising directly or indirectly in connection with, in relation to or arising out of the use of the Content.

This article may be used for research, teaching, and private study purposes. Any substantial or systematic reproduction, redistribution, reselling, loan, sub-licensing, systematic supply, or distribution in any form to anyone is expressly forbidden. Terms \& Conditions of access and use can be found at http:// www.tandfonline.com/page/terms-and-conditions 


\title{
Conversion of switchgrass to ethanol using dilute ammonium hydroxide pretreatment: influence of ecotype and harvest maturity ${ }^{\dagger}$
}

\author{
Bruce S. Dien ${ }^{\mathrm{a} *}$, Patricia J. O’Bryan ${ }^{\mathrm{a}}$, Ronald E. Hector ${ }^{\mathrm{a}}$, Loren B. Iten ${ }^{\mathrm{a}}$, Robert B. Mitchell ${ }^{\mathrm{b}}$, Nasib Qureshi ${ }^{\mathrm{a}}$, \\ Gautum Sarath $^{\mathrm{b}}$, Kenneth P. Vogel ${ }^{\mathrm{b}}$ and Michael A. Cotta ${ }^{\mathrm{a}}$ \\ ${ }^{a}$ Bioenergy Research Unit, National Center for Agricultural Utilization Research, USDA, Agricultural Research Service, 1815 N. \\ University Street, Peoria, IL 61604-3902, USA, ${ }^{b}$ Grain, Forage, and Bioenergy Research Unit, University of Nebraska, 137 Keim Hall, \\ Box 830937, Lincoln, NE 68583-0937, USA
}

(Received 29 March 2013; accepted 20 May 2013)

\begin{abstract}
Switchgrass (Panicum virgatum L.) is a perennial C4 grass that is being developed as a bioenergy crop because it has high production yields and suitable agronomic traits. Five switchgrass biomass samples from upland and lowland switchgrass ecotypes harvested at different stages or maturity were used in this study. Switchgrass samples contained 317.0-385.0 g glucans $/ \mathrm{kg}$ switchgrass dry basis $(\mathrm{db})$ and 579.3-660.2 g total structural carbohydrates $/ \mathrm{kg}$ switchgrass, $\mathrm{db}$. Carbohydrate contents were greater for the upland ecotype versus lowland ecotype and increased with harvest maturity. Pretreatment of switchgrass with dilute ammonium hydroxide $\left(8 \% \mathrm{w} / \mathrm{w}\right.$ ammonium loading) at $170^{\circ} \mathrm{C}$ for $20 \mathrm{~min}$ was determined to be effective for preparing switchgrass for enzymatic conversion to monosaccharides; glucose recoveries were $66.9-90.5 \%$ and xylose recoveries $60.1-84.2 \%$ of maximum and decreased with increased maturity at harvest. Subsequently, pretreated switchgrass samples were converted to ethanol by simultaneous saccharification and fermentation using engineered xylose-fermenting Saccharomyces cerevisiae strain YRH400. Ethanol yields were 176.2-202.01/Mg of switchgrass (db) and followed a similar trend as observed for enzymatic sugar yields.
\end{abstract}

Keywords: switchgrass; bioethanol; simultaneous saccharification and fermentation; pretreatment; bioenergy crop

\section{Introduction}

Increased concerns in regard to climate change have led governments around the world to promote research directed towards the commercialization of renewable fuels. Bioethanol is the dominant renewable transportation fuel with global annual production of 85.2 billion litres (www.ethanolraf.org accessed 18 March 2013). The leading producers are the USA and Brazil, which rely on corn (Zea maize) and sugar cane (Saccharum spp.), respectively. However, recent advances in research have led to early stage commercialization of lignocellulosic feedstocks for biofuel production by several companies using a variety of approaches.[1] Lignocellulose represents a significant sized potential resource for producing biofuels. For USA alone, it has been estimated that at a farm gate price of $\$ 60$ per dry US tonnes, there could be 602-1009 million dry US tonnes available by 2022.[2] This amount of biomass could be used to produce in excess of 20 billion gallons of cellulosic biofuels in addition to the current grain ethanol production of 13.3 billion gallons in the USA (www.ethanolrfa.org/pages/statistics accessed 18 March
2013). It is estimated that 282 million dry tonnes per year of the expected biomass will be harvested from dedicated bioenergy crops.[2]

Switchgrass (Panicum virgatum L.) is a warm season perennial grass that is being developed as a dedicated energy crop in the USA and other temperate regions of the world because it is a high-yielding perennial crop that can be grown on marginal land not well suited for food crop production. Switchgrass also has positive soil conservation, soil carbon sequestration, and net energy benefits making it well suited for development as a bioenergy crop.[3-6] In particular, it is predicted that conversion of the switchgrass to ethanol would result in a $540 \%$ renewable energy return on non-renewable energy inputs and $94 \%$ lower green house gases (GHG) emissions than that of gasoline.[6]

Switchgrass has two major ecotypes: lowland ecotypes are found in flood plains and upland ecotypes are found in better drained, upland soil.[3] Upland ecotypes are preferred for forage production for animal feed because they have finer stems than do lowland ecotypes; however, lowland ecotypes have higher yields, and therefore are expected

\footnotetext{
*Corresponding author. Email: bruce.dien@ars.usda.gov

${ }^{\dagger}$ Names are necessary to report factually on available data; however, the USDA neither guarantees nor warrants the standard of the product, and the use of the name by USDA implies no approval of the product to the exclusion of others that may also be suitable.
} 
to be superior for bioenergy applications.[3] Biomass yield and composition depend on plant maturity at the time of the harvest. Maximum biomass yield $(\mathrm{Mg} / \mathrm{ha})$ typically occurs at anthesis and decreases $10-20 \%$ until the first killing frost.[3] However, anthesis may not be the optimal harvest time because following frost, nitrogen and other nutrients are relocated to the plant roots. In some native grasses, internal cycling of nitrogen can meet $18 \%$ of a field's annual need, which is beneficial because this reduces fertilizer requirements and fertilizer represents a major energy input and source of GHG emission in the form of nitrous oxide.[5] While much is known about growing grasses for forage quality, less is known in regard to producing grasses for bioenergy applications. In this study, biomass from both upland and lowland ecotypes harvested at different maturity stages were included as variables.

Conversion of lignocelluloses to ethanol is a multi-step process.[7] Following milling, the biomass is pretreated typically using a combination of heat and chemicals. Pretreatment deconstructs the plant cell wall, displacing the lignin and removing the xylan, and alters the native cellulose fibres to promote its hydrolysis by cellulose. [8,9] The success of pretreatment is often measured by digesting the sample in the presence of cellulases and associated enzymes at low solids.[10] Less than $20 \%$ of the available glucose is liberated by cellulases from untreated switchgrass.[11] The sugars produced by enzymatic hydrolysis are a mixture dominated by glucose and xylose. Saccharomyces yeast, the preferred commercial microorganism for industrial ethanol production, is unable to consume xylose. One solution is to use a Saccharomyces cerevisiae strain engineered for xylose fermentation.[12] Often enzymatic hydrolysis and fermentation are conducted in a single step, termed as simultaneous saccharification and fermentation (SSF). SSF requires less enzyme loading than when the steps are carried out sequentially because liberated glucose is continually fermented by the yeast, which avoids end product inhibition of the cellulases.

In this study, the upland cultivar Cave-in-Rock (CIR) and the USDA-ARS experimental strain Kanlow N1,[13] which is a lowland ecotype strain, were harvested at various maturities and the collected biomass evaluated for conversion to ethanol. This is significant because much of the prior literature does not consider the influence of both genetics and harvest maturity on processing and product yields. Many pretreatment methods have been evaluated for switchgrass.[14-16] Dilute ammonia was selected as the pretreatment method based upon prior success with other herbaceous species [17-19] and because ammonia can be removed by evaporation and recycled. Following optimization of pretreatment conditions, the sample set of cultivars was evaluated for enzymatic saccharification to sugars and conversion to ethanol using SSF cultures. To maximize ethanol yields, S. cerevisiae YRH400 was used because it has been engineered to ferment xylose.[20]

\section{Materials and methods \\ Materials}

Switchgrass samples were harvested at various maturities from established plots located at Mead, NE. Five samples were used for this study, which were labelled MPV1MPV5. The three CIR samples were harvested at pre-boot (MPV1), anthesis (MPV2), and post-frost (MPV3). The two Kanlow N1 samples were harvested at anthesis (MPV4) and post-frost (MPV5). Following collection, the biomass was air dried on greenhouse benches and ground in a Wiley Mill so as to pass through a $1-\mathrm{mm}$ screen.

The enzymes Cellulase Optiflow RC2, Multifect Pectinase, Multifect Xylanase, and $\beta$-xylosidase were kindly donated by Genencor, Inc. (Rochester, NY) and Novo188 $\beta$-glucosidase (Novozymes A/S, Denmark) were purchased from Sigma-Aldrich Chemical Co. (St. Louis, MO). Pluronic F68 block copolymer surfactant was also purchased from Sigma-Aldrich Chemical Co. Other reagents and chemicals were purchased from either Sigma-Aldrich Chemical Co. or Thermo Fisher Scientific Inc. (Waltham, MA) and were of research quality. The yeast strains used were S. cerevisiae D5A (American Type Culture Collect strain 200062) and YRH400. Strain YRH400 was constructed by integrating the genes for xylose utilization (xylose reductase, xylitol dehydrogenase, and xylulokinase) into the D5A genome as previously described.[20] Strain D5A has been recommended for fermentation evaluations of biomass.[21] Enzymes used for fermentation were filter sterilized by passing through $0.2 \mu \mathrm{m}$ syringe filters and all other additions were sterilized by heating at $121^{\circ} \mathrm{C}$ in an autoclave.

\section{Compositional analysis}

Structural carbohydrates (cellulose, xylan, and arabinan) were determined for unextracted biomass according to the analytical procedure of the National Renewable Energy Laboratory (NREL) [22] using the two-stage $\mathrm{H}_{2} \mathrm{SO}_{4}$ digestion protocol. Moisture contents were determined by drying samples in a static oven at $105^{\circ} \mathrm{C}$ for $18-24 \mathrm{~h}$. All biomass masses are given on a dry weight basis (db).

\section{Pretreatment processes}

Switchgrass at $15 \% \mathrm{w} / \mathrm{w}$ solids loading was mixed with dilute ammonium hydroxide $(2-8 \% \mathrm{w} / \mathrm{w}$ ammonia basis as indicated in text) in 316 stainless steel (SS) mini-batch reactors. The reactors were sized either at $25 \mathrm{ml}$ volume (3/4 in. OD) or at $68 \mathrm{ml}(1 \mathrm{in} . \mathrm{OD})$ and constructed of 316 SS and tubing capped on both ends with SS compression fittings. The reactors were heated to $160-180^{\circ} \mathrm{C}$ in a fluidized heating aluminium sand bath (SBL-1, Techne Inc., Burlington, NJ) equipped with a temperature controller (Techne TC-8D temperature controller). A separate reactor of the same type was fitted with an internal Type K air immersion thermocouple to monitor temperature. The 
reactions were quenched by transferring the reactors to a water bath. Reactors required approximately $8 \mathrm{~min}$ to achieve the reaction temperature and cooled to near ambient temperature in under $2 \mathrm{~min}$. Ammonia was removed by evaporation at ambient temperature. Once evaporated, the resulting solids were used as is and specifically were not washed. Unless stated otherwise in the text, switchgrass was pretreated with $8 \% \mathrm{w} / \mathrm{w}$ ammonium at $170^{\circ} \mathrm{C}$ for $20 \mathrm{~min}$.

\section{Enzymatic hydrolysis}

Cellulose digestibility was determined using a modified version of an NREL procedure.[23] The whole hydrolysate (solid and liquid fraction) was diluted to $3 \%$ solids by adding sodium citrate buffer (final concentration $50 \mathrm{mM}$, $\mathrm{pH}$ 4.8) supplemented with the antibacterial agent thymol $(500 \mathrm{mg} / \mathrm{l})$. The enzymatic digestion was initiated by adding Optiflow RC2 cellulase (30 FPU/g cellulose) and Novo188 $\beta$-glucosidase ( $40 \mathrm{U} / \mathrm{g}$ cellulose). Various reactions were supplemented with the following: Pluronic F68 surfactant $(16 \% \mathrm{w} / \mathrm{w})$, Multifect Pectinase $(50 \mathrm{U} / \mathrm{g}$ switchgrass), Multifect Xylanase (50 U/g switchgrass), and $\beta$-xylosidase ( $1250 \mathrm{U} / \mathrm{g}$ switchgrass). The reaction was carried out at $50^{\circ} \mathrm{C}$ for $72 \mathrm{~h}$ while mixing at $125 \mathrm{rpm}$ using an incubator/shaker $\left(\right.$ Innova ${ }^{\circledR}$, New Brunswick Scientific, NJ). Digested samples were analysed for soluble carbohydrates and monosaccharides as described below. All enzymatic saccharification reactions were conducted at least in duplicate.

\section{Ethanol fermentation}

\section{Bottle SSFs}

Fermentations were conducted with a switchgrass solids loading of $10 \% \mathrm{w} / \mathrm{v}$. The ammonia-pretreated sample $(1.0 \mathrm{~g})$ was placed in a capped $25 \mathrm{ml}$ Pyrex bottle (Corning glass, NY) and sterilized by heating at $121^{\circ} \mathrm{C}$ for $15 \mathrm{~min}$ using an autoclave followed by the addition of $8.5 \mathrm{ml}$ of sterile $\mathrm{dH}_{2} \mathrm{O}, 0.5 \mathrm{ml}$ of $1 \mathrm{M}$ sodium citrate buffer $(50 \mathrm{mM}$ final concentration, $\mathrm{pH} 4.8$ ), $1.0 \mathrm{ml}$ of YP basal $10 \times$ stock (for a final concentration of $10 \mathrm{~g} / 1$ yeast extract and $20 \mathrm{~g} / 1$ peptone), and Pluronic F68 surfactant (16\% w/w switchgrass). The following enzymes were added to the SSFs: Optiflow RC2 (15 FPU/g glucan), Novo188 (40 U/g glucan), Multifect pectinase (50 U xylanase activity/g biomass) and $\beta$-xylosidase ( $1250 \mathrm{U} / \mathrm{g}$ biomass). The cellulase loading used for SSF is half that used for the enzymatic digestion experiments because glucose inhibition of cellulases is avoided by the addition of the yeast, which ferments glucose as it forms. Control fermentations without added biomass were used to determine background glucose and ethanol, which were subtracted (these were minimal values).

Fermentation vessels were capped by screw top bottles with silicone septa inserts; each septum was pierced with a $22 \mathrm{~g}$ needle to exhaust $\mathrm{CO}_{2}$. The fermentations were inoculated to an $\mathrm{OD}_{600}$ of 1.0 yeast biomass $(1.0 \mathrm{~cm}$ path, DU 640 Spectrophotometer, Beckman, Brea, CA). The bottles were incubated for $72 \mathrm{~h}$ at $35^{\circ} \mathrm{C}$ while mixing at $100 \mathrm{rpm}$ using an incubator shaker (Inova 4230, New Brunswick, NJ). Cultures were analysed for ethanol, xylitol, and residual sugar concentrations using high pressure liquid chromatography (HPLC).

\section{Pressure production module SSFs}

Fermentation yield and rates for xylose-fermenting yeast YRH400 and its parental strain D5A were compared using batch fermentation modules that allowed for collection of gas production data. For these experiments, each reactor had $10 \mathrm{~g}$ switchgrass (dry basis (db)) added and all other additions were kept at the same proportion as described for the bottle fermentations. Fermentation conditions were the same except cultures were mixed at $150 \mathrm{rpm}$ using a $3 \times 4$ in. Teflon ${ }^{\mathrm{TM}}$ coated cross-shaped stirring bar and a sixposition magnetic stirrer (Vero Variomag Poly 6 Multipoint Stirrer, Cole-Parmer, Vernon Hills, IL). The fermentation vessel consisted of a $100 \mathrm{ml}$ threaded Pyrex ${ }^{\mathrm{TM}}$ bottle and capped with a pressure sensor top (see below).

Fermentation progress was continually monitored by measuring carbon dioxide gas production; carbon dioxide is produced stoichiometrically with ethanol. Carbon dioxide production was monitored using the Ankom wireless gas production system (Ankom Technology, Macedon, NY) set to vent at $1.0 \mathrm{psi}$ over-pressure. The system included pressure monitoring caps, a wireless receiver for collecting pressure data equipped with a USB connection to a computer and a software program for recording the pressure and setting the device parameters. The cap fitted on top of the threaded fermentation bottle with a gas-tight fit and contained a pressure transducer that continually monitored gas pressure in the headspace, a wireless transmitter, a rechargeable battery, and a valve for venting gas to prevent over-pressuring. Cumulative gas production was calculated from the recorded gas pressure data using the ideal gas law.

\section{Inoculum preparation}

The inoculum was prepared for all fermentations by transferring a colony grown on solid YP2D (YP supplemented with $20 \mathrm{~g} / 1$ dextrose and $2.0 \%$ Bacto agar) to a liquid YP2D culture followed by a YP5D culture (YP supplemented with $50 \mathrm{~g} / 1$ dextrose). The liquid cultures were grown for $18 \mathrm{~h}$ at $35^{\circ} \mathrm{C}$ and $200 \mathrm{rpm}$, and the cells were harvested from the YP5D culture by centrifugation and concentrated to a cell solution of $50 \mathrm{OD}_{600}$ in PPB (per L: $8.5 \mathrm{~g} \mathrm{NaCl}$, $0.3 \mathrm{~g} \mathrm{KH}_{2} \mathrm{PO}_{4}, 0.6 \mathrm{~g} \mathrm{Na}_{2} \mathrm{HPO}_{4}, 0.4 \mathrm{~g}$ peptone). Fermentation cultures were inoculated to an $\mathrm{OD}_{600}$ of 1.0 from the concentrated cell solution. Experiments were conducted at least in duplicate.

\section{Analytical methods}

Samples were dried at $105^{\circ} \mathrm{C}$ for $18-24 \mathrm{~h}$ for moisture determinations; all solid loadings were referenced to these 
moisture contents. Samples used for moisture determinations were discarded.

Cellulase, $\beta$-glucosidase, xylanase, $\beta$-xylosidase activities were measured as previously reported.[24] Total soluble carbohydrates (e.g. soluble xylans/xylose) were analysed by HPLC after being end point hydrolysed by treating with $2 \mathrm{M}$ trifluoroacetic acid for $1 \mathrm{~h}$ at $100^{\circ} \mathrm{C}$. Total soluble xylan/xylose includes the sum of xylose and soluble xylans freed by the trifluoroacetic acid digestion. Samples were analysed for sugars, organic acids, and ethanol using a SpectraSYSTEM ${ }^{\mathrm{TM}}$ liquid chromatography system (Thermo Electron Corporation, CA) equipped with an automatic sampler, column heater, isocratic pump, refractive index detector, and computer-based integrator running Chromquest ver. 2.5 (Thermo Electron Corporation, CA). Samples $(20 \mu 1)$ were injected onto a sugar analysis column (Aminex HPX-87H Column, $300 \times 7.8$ mm, Bio Rad Laboratories, Inc., Hercules, CA) and eluted with $5 \mathrm{mM}$ sulphuric acid at $0.6 \mathrm{ml} / \mathrm{min}$ and $65^{\circ} \mathrm{C}$, as previously described.[25]

\section{Calculations}

Yields $(\mathrm{g} / \mathrm{kg})$ are reported as gram of product per kilogram of beginning biomass on a db. Glucose conversion efficiencies were then calculated from the ratio of glucose released following cellulase treatment and the beginning cellulose content, adjusted for the mass gained through hydrolysis. Ethanol efficiencies from the fermentations of pretreated samples were calculated from the ratio of ethanol produced and maximum theoretical ethanol. The latter was calculated based upon the beginning glucan content by the theoretical conversion coefficient for ethanol production $(0.567 \mathrm{~g}$ ethanol/g glucan), and additionally by multiplying the beginning glucan and xylan contents by 0.567 and $0.580 \mathrm{~g}$ ethanol per gram of glucan and xylan, respectively.[10]
Design and analysis of the factorial experiment used for formulating the enzyme mixture was done using Design-Expert (version 7.0.3, Stat-Ease, Inc., Minneapolis, MN). The effect for adding pectinase, surfanctant, and xylanase were evaluated using a full factorial with a centre block run in triplicate. The effect of adding $\beta$-xylosidase was evaluated using a full factorial without centre points.

\section{Results}

\section{Composition of switchgrass samples}

The samples were analysed for structural carbohydrates, acetyl groups, and Klason lignin (Table 1). Carbohydrate content is the most important trait for biochemical processing to biofuels because it directly determines the potential yield of ethanol. The switchgrass samples contained approximately $62 \% \mathrm{w} / \mathrm{w}$ structural carbohydrates. The amounts of structural carbohydrates were fairly uniform with MPV1 containing the least (4\% less than the mean) and MPV5 containing the most (4\% more). This corresponds to potential ethanol yields for samples MPV1MPV5 of 394, 422, 431, 438, and 4591/Mg, respectively, assuming complete conversion of glucans and xylans. Most recombinant yeast strains are currently unable to ferment arabinose.[26] While increased lignin increases the heating value of the biomass, it has been observed to impede enzymatic extraction of the carbohydrates (one example: [19]). Therefore, for biochemical conversion, greater lignin contents are generally considered unfavourable. In this case, Klason lignin content increased with harvest maturity for both lowland and upland biomass samples.

\section{Optimization of ammonium hydroxide pretreatment}

The ammonium hydroxide pretreatment reaction conditions were optimized for ammonia concentration, time, and

Table 1. Composition for native and post-pretreated switchgrass samples $(\mathrm{g} / \mathrm{kg}, \mathrm{db})$.

\begin{tabular}{|c|c|c|c|c|c|c|c|}
\hline Cultivar & $\begin{array}{l}\text { Harvest } \\
\text { maturity }\end{array}$ & Glucan $^{\mathrm{a}}$ & Xylan & Arabinan & Acetate & $\begin{array}{c}\text { Total Klasson } \\
\text { lignin }\end{array}$ & Carbohydrates \\
\hline \multicolumn{8}{|c|}{ Native biomass composition } \\
\hline MPV $1^{b}$ & Pre-boot & $317.1 \pm 0.7^{\mathrm{c}}$ & $223.7 \pm 0.05$ & $38.5 \pm 0.1$ & $33.6 \pm 0.1$ & $128.8 \pm 1.9$ & 579.3 \\
\hline MPV2 & Anthesis & $361.1 \pm 2.8$ & $218.8 \pm 1.8$ & $32.6 \pm 0.1$ & $35.1 \pm 2.1$ & $141.6 \pm 1.7$ & 612.5 \\
\hline MPV3 & Post-frost & $354.5 \pm 2.8$ & $237.9 \pm 0.6$ & $34.2 \pm 2.2$ & $39.9 \pm 0.1$ & $167.4 \pm 11.0$ & 626.6 \\
\hline MPV4 & Anthesis & $363.1 \pm 3.4$ & $238.7 \pm 0.1$ & $29.7 \pm 0.3$ & $45.9 \pm 0.4$ & $160.3 \pm 4.43$ & 631.5 \\
\hline MPV5 & Post-frost & $385.0 \pm 7.3$ & $245.6 \pm 0.6$ & $29.7 \pm 0.2$ & $49.1 \pm 03$ & $165.0 \pm 24.5$ & 660.3 \\
\hline \multicolumn{8}{|c|}{ Post-pretreatment composition } \\
\hline MPV1 & Pre-boot & $320.3 \pm 0.8$ & $219.3 \pm 0.5$ & $44.8 \pm 0.1$ & $26.2 \pm 2.2$ & & 584.4 \\
\hline MPV2 & Anthesis & $363.2 \pm 5.1$ & $222.5 \pm 5.4$ & $41.5 \pm 0.6$ & $30.6 \pm 0.4$ & & 627.2 \\
\hline MPV3 & Post-frost & $357.6 \pm 0.7$ & $237.5 \pm 0.1$ & $40.4 \pm 1.7$ & $30.9 \pm 0.3$ & & 635.5 \\
\hline MPV4 & Anthesis & $356.6 \pm 1.2$ & $234.2 \pm 0.5$ & $38.6 \pm 0.1$ & $27.6 \pm 0.1$ & & 629.4 \\
\hline MPV5 & Post-frost & $374.2 \pm 2.0$ & $239.4 \pm 2.3$ & $38.7 \pm 0.0$ & $33.8 \pm 0.0$ & & 652.3 \\
\hline
\end{tabular}

${ }^{a}$ Glucans include starch. Starch contents for MPV1-MPV5 were 3.47, 61.50, 2.00, 2.55, and 1.78 g/kg, respectively.

${ }^{b}$ MPV1-MPV3 are CIR upland ectoype variety and MPV4 and MPV5 are Kanlow N1 lowland ecotype variety.

${ }^{\mathrm{c}}$ Standard deviation of duplicate samples. 


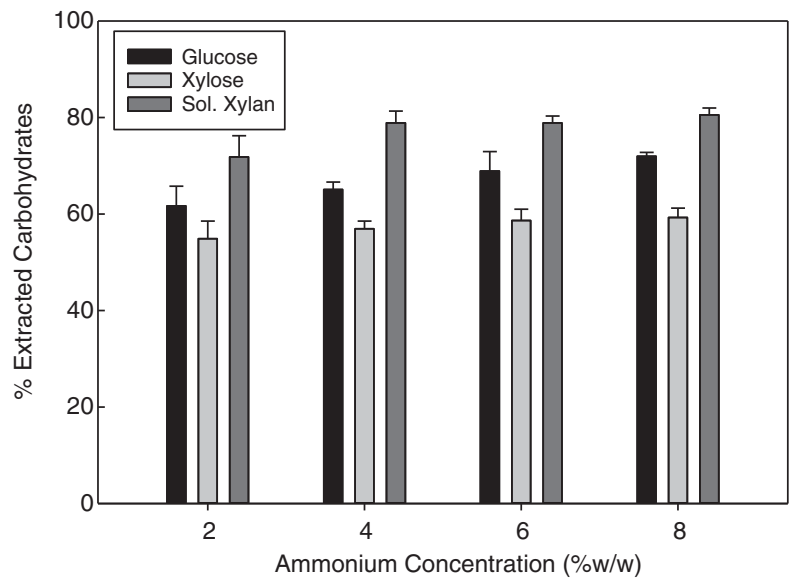

Figure 1. Switchgrass MPV3 was preatreated with various ammonia loadings at $170^{\circ} \mathrm{C}$ for $20 \mathrm{~min}$ followed by enzymatic hydrolysis. Glucose, xylose, and soluble xylan/xylose are presented as percentage of maximum.

temperature. The post-frost harvested CIR (MPV3) sample was used for this series of experiments because it was among the most recalcitrant. The pretreated samples were evaluated for enzymatic saccharification using cellulases supplemented with $\beta$-glucosidase. The digested samples were analysed for glucose, xylose, and soluble xylan/xylose (Figure 1). The glucose yield (e.g. cellulose hydrolysis) increased with ammonia loading up to $8 \% \mathrm{w} / \mathrm{w}$ from $62 \%$ to $72 \%$ of available glucan. Xylose yield was largely invariant with ammonia concentration. Soluble xylan/xylose yield, however, increased in a similar manner to glucose with ammonia loading from $72 \%$ to $81 \%$ of maximum. Soluble xylan/xylose was measured by end digesting the liquid fraction with acid at $100^{\circ} \mathrm{C}$. The removal of xylan (e.g. corresponding to production of soluble xylan/xylose) has been correlated with cellulose accessibility as measured by increasing glucose yield.[27] Thus, increased xylan solubilization is a favourable result. That xylose did not increase in conjunction with soluble xylan/xylose reflects a shortcoming of the enzyme cocktail because alkaline pretreatments depend upon enzymes for conversion of xylan into xylose. Therefore, to maximize the glucose yield and extent of xylan removal, the ammonia loading was set to $8 \% \mathrm{w} / \mathrm{w}$.

To see if the sugar yields could be further increased, the reaction time and temperature were varied between $160-180^{\circ} \mathrm{C}$ and $0-20 \mathrm{~min}$ (Figure 2(a) and 2(b)). The $0 \mathrm{~min}$ sample measured the effect of heating the sample to the reaction temperature. While glucose increased with temperature and time, the largest change was observed for the transition from $160^{\circ} \mathrm{C}$ to $170^{\circ} \mathrm{C}$. For example, increasing from $170^{\circ} \mathrm{C}$ to $180^{\circ} \mathrm{C}$ at 20 min residence time only increased the glucose yield by $3 \%$. The yields were similar for either $10 \mathrm{~min}$ at $180^{\circ} \mathrm{C}$ or $20 \mathrm{~min}$ for $170^{\circ} \mathrm{C}$ (Figure 2(a)). Soluble xylan/xylose followed a similar trend except the maximum soluble xylan/xylose was observed at $170^{\circ} \mathrm{C}$ for $20 \mathrm{~min}$
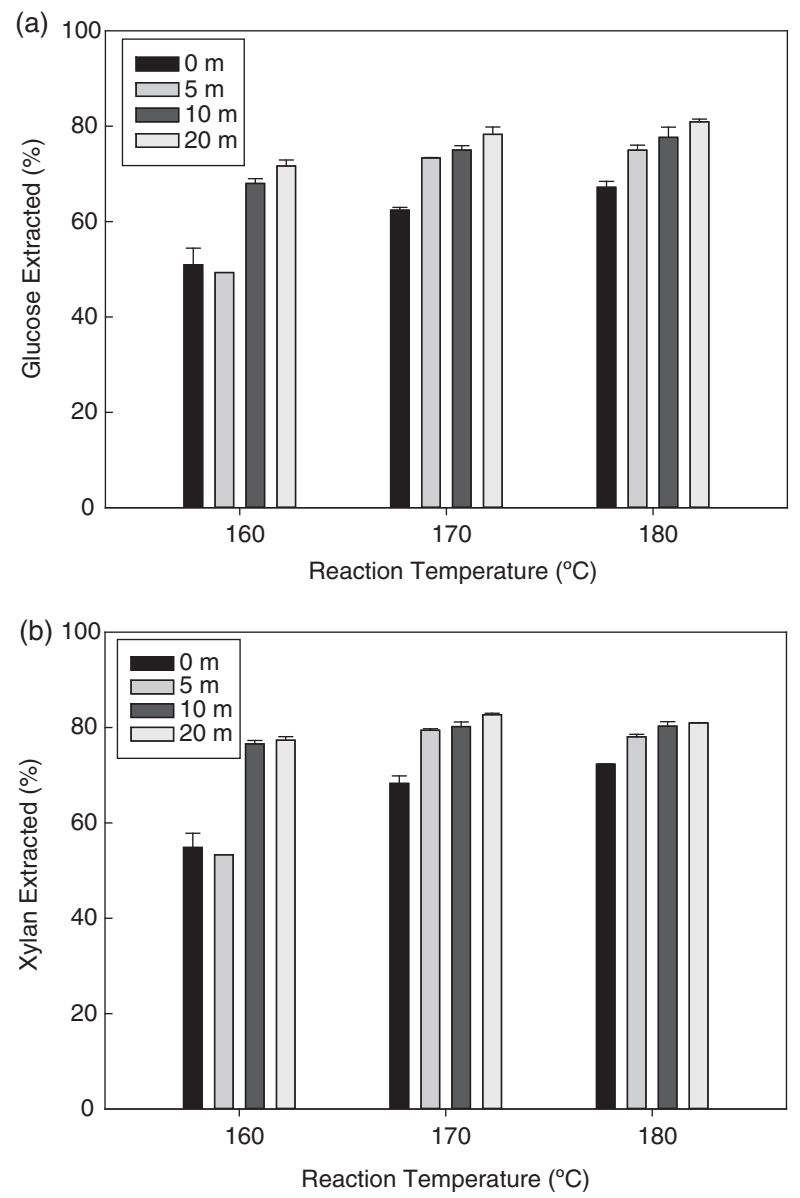

Figure 2. (a) and (b) Effect of reaction time and temperature on (a) glucose and (b) soluble xylan/xylose production as percentage of maximum. Ammonia concentration was kept constant at $8 \%$. Reaction times evaluated were 0, 5, 10, and $20 \mathrm{~min}$. Error bars are standard deviations.

(Figure 2(b)). The lower temperature of $170^{\circ} \mathrm{C}$ was selected to minimize ammonia vapour pressure and energy inputs.

While commercial cellulases contain substantial side activities suitable for hydrolysing hemicelluloses, it was expected that the enzyme mixture was not appropriately balanced because of incomplete saccharification of xylooligomers. A more balanced enzyme mixture would serve to increase both the xylose and glucose yields. More complete extraction of insoluble xylan from the plant cell wall would be expected to increase access to the insoluble cellulose fibres for enzymatic cleavage resulting in increased glucose yields.[27] The cellulase enzyme mixture was supplemented with commercial xylanase, pectinase, and a surfactant. The surfactant may increase cellulose conversion by lowering the surface tension on the cellulose fibre surface and/or blocking non-specific lignin binding of cellulases.[28] To streamline the experiment, a partial factorial experimental design was used with replicated center point and the responses for glucose and xylose yield described with a linear model (adjusted $r^{2}=0.87$ ). Additions of surfactant, pectinase, and xylanase as well as a 


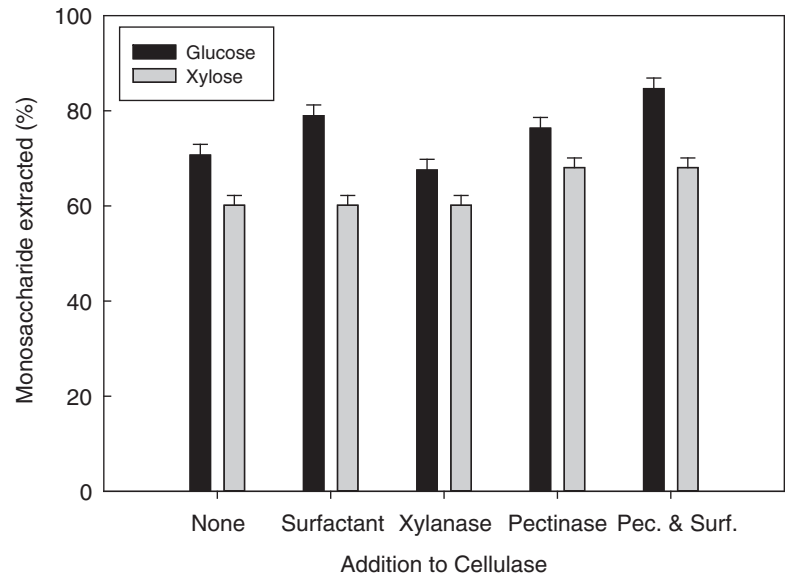

Figure 3. Pretreated switchgrass MPV3 was hydrolysed with cellulases and various additions. Error bars represent the 95\% confidence interval.

positive interaction between surfactant and pectinase were significant at the $1 \%$ level. Results from the model are shown in Figure 3. The highest glucose yield (84.7\%) was observed when cellulases were supplemented with pectinase and surfactant. The maximum xylose yield was only $68.1 \%$. It is notable that while switchgrass contains only minor amounts of pectin (data not shown), the commercial pectinase preparation contains side activities that promote hydrolysis of arabinoxylan.

One possibility is that there was insufficient $\beta$-xylosidase to overcome end product inhibition, thereby impeding the conversion of xylooligomers to xylose. To test this hypothesis, the new enzyme cocktail (a mixture of cellulase, $\beta$-glucosidase, pectinase, and surfactant) was supplemented with additional $\beta$-xylosidase. Adding $\beta$-xylosidase increased the extraction of xylose by $7.9 \%$ and of glucose by $3.1 \%$ (data not shown). It might seem unexpected that $\beta$ xylosidase would also increase the glucose yield. However, xylooligomers can inhibit cellulases and lower cellulose conversion.[29] Therefore, both of these results suggest the original enzyme mixture is deficient in $\beta$-xylosidase. The selected enzyme cocktail consisted of Optiflow RC2 cellulase ( $30 \mathrm{FPU} / \mathrm{g}$ cellulose), Novo188 $\beta$-glucosidase ( $40 \mathrm{U} / \mathrm{g}$ cellulose), Pluronic F68 surfactant $(16 \% \mathrm{w} / \mathrm{w})$, Multifect Pectinase (50 U/g switchgrass), and $\beta$-xylosidase (6667 U/g switchgrass).

Next, the pretreated switchgrass was fermented to ethanol. An SSF scheme was used, whereby the enzymes and yeast are co-added to facilitate cellulose conversion. The yeast consumes the glucose as soon as it is released by the cellulases. This prevents end product inhibition of the $\beta$-glucosidase and has been observed to give higher ethanol yields at lower enzyme loadings. For SSF experiments, cellulase loading was reduced in half from that applied for the enzymatic saccharification experiments. Two yeast strains were evaluated on the pretreated switchgrass: D5A and YRH400. Strain YRH400 is engineered for

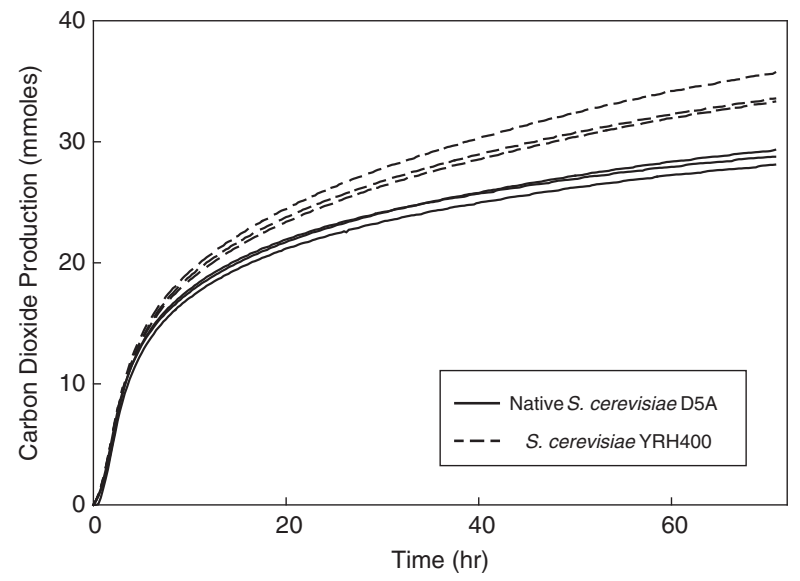

Figure 4. Fermentation profile for SSF of ammonia-pretreated switchgrass MPV3 as measured by online $\mathrm{CO}_{2}$ production. Pretreated switchgrass MPV3 was SSF using $S$. cerevisiae D5A and xylose-fermenting YRH400.

xylose fermentation,[20] which is advantageous because on average xylose is $37 \%$ of the switchgrass carbohydrate content. Strain D5A is the parental strain of YRH400 and served as a control because it is unable to ferment xylose. Strain YRH400 did produce $11.4 \%$ more ethanol than D5A $(14.3 \pm 0.35$ vs. $12.5 \pm 0.06 \mathrm{~g} / \mathrm{l})$. Though significant, this increase is hardly the $37 \%$ that might have been expected. However, YRH400 did not ferment all of the available xylose (residual xylose $=6.34 \mathrm{~g} / \mathrm{l}$ ) and much of the xylose was funnelled to xylitol $(8.69 \mathrm{~g} / \mathrm{l})$. In the original publication describing strain YRH400, residual xylose and excess xylitol production were also observed for mixed sugar fermentations.[20]

The fermentation progress was monitored on line by measuring carbon dioxide production, which is stoichiometric with ethanol production. In agreement with ethanol measurements, the YRH400 cultures produced more carbon dioxide than D5A (Figure 4). Two notable characteristics are both strains have the same initial productivity and the absence of a significant lag phase. The first observation suggests that expression of the xylose metabolism pathway does not interfere with glucose metabolism and the second that the pretreated switchgrass is benign when using dilute ammonia pretreatment. This second observation is of particular importance because pretreatment often leads to the formation of side products that inhibit microbial growth and fermentation.[30,31] As a consequence, hydrolysate fermentations are frequently observed to have extended lag phases [32] as the microorganisms (in part) partially detoxify aldehyde groups to their less toxic alcohol forms.[33] The similarity in productivities is further evidence for the absence of inhibitors.

To summarize, ammonia-based pretreated process for converting switchgrass to ethanol has been optimized using the CIR post-frost sample (MPV3). The chosen pretreatment conditions were $8 \% \mathrm{w} / \mathrm{w}$ ammonia loading at $170^{\circ} \mathrm{C}$ 
Table 2. Mass balance for ammonia-pretreated switchgrass MPV3 through entire process.

\begin{tabular}{|c|c|c|c|c|c|c|c|}
\hline \multirow{3}{*}{$\begin{array}{l}\text { Component: } \\
\text { Total (g): }\end{array}$} & \multirow{3}{*}{$\begin{array}{c}\text { Native SG } \\
\text { Untreated (A) } \\
1000\end{array}$} & \multicolumn{3}{|c|}{ Pretreated biomass } & \multicolumn{3}{|c|}{$\begin{array}{l}\text { Enzymatic hydrolysis } \\
\text { of pretreated solids }(\mathrm{C})\end{array}$} \\
\hline & & Liquid $^{\mathrm{a}}$ (B) & Solid $^{\mathrm{a}}(\mathrm{C})$ & $\begin{array}{l}\text { Total } \\
\text { recovery }\end{array}$ & Liquid $^{\mathrm{a}}(\mathrm{D})$ & Solid $^{\mathrm{a}}(\mathrm{E})$ & $\begin{array}{l}\text { Total } \\
\text { recovery }\end{array}$ \\
\hline & & 390 & 560 & 950 & 381 & 179 & 560 \\
\hline Glucan (g) & 342 & 13 & 305 & 318 & 227 & 45 & 272 \\
\hline Xylan (g) & 235 & 65 & 162 & 227 & 118 & 15 & 133 \\
\hline Lignin (g) & 167 & nd & 97 & 97 & nd & 86 & 86 \\
\hline
\end{tabular}

Notes: Column shades match those presented in Figure 5. Yields are reported in grams recovered on a $1 \mathrm{~kg}$ switchgrass basis. Each number is the mean of four replicates. The process stream in the figure and corresponding column are labelled with the same letter code.

${ }^{a}$ Liquid and solid fractions as separated by centrifugation and subsequent washing of the recovered solids.

for $20 \mathrm{~min}$. The pretreated switchgrass was enzymatically hydrolysed using a combination of cellulases and pectinases supplemented with added $\beta$-glucosidase and $\beta$-xylosidase. Pectinase was included in the digestion experiment because it has a wide range of side activities pertinent to hydrolysing arabinoxylan [34]; switchgrass does not contain significant amounts of pectin.

\section{Mass balance for ammonium pretreatment process}

To better define the optimized process, switchgrass MPV3 was processed to sugars and the fate of carbohydrates and lignin tracked throughout. Following pretreatment, the solids and liquid were separated and the solids were washed thoroughly with water. The washed solids were subsequently treated with enzymes and the digested hydrolysate separated into liquid and solids phases. At each step, the solids and liquids were examined for total mass and carbohydrates and the solids additionally for Klason lignin. This process varied from the standard protocol where the solids and liquid were dried together following pretreatment. Dispensing with separation of the liquid and solid fractions is an advantage of ammonia pretreatment compared with most other pretreatments; the solids and liquids were separated in this case to facilitate the mass balance description.

The mass balance is listed in Table 2 and the shades of the columns are keyed to a diagram describing the mass balance (Figure 5). Following pretreatment, $56 \%$ of the switchgrass remained with the solids which included most

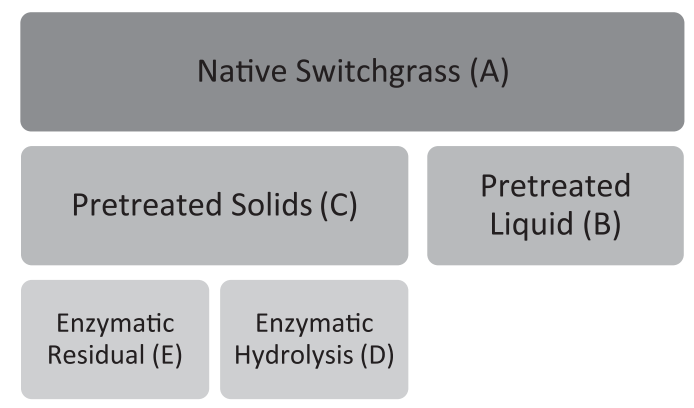

Figure 5. Process product steams from conversion of pretreated switchgrass MPV3. Shades are keyed to Table 2. of the glucans, xylan, and lignin. The liquid contained unidentified extractables and $28 \%$ of the xylan. Approximately $93 \%$ of the glucan and $96 \%$ of xylan were recovered following pretreatment with a $95 \%$ total mass recovery. Following treatment of the solids with the enzyme cocktail, $73 \%$ of the glucans and $89 \%$ of the xylan were saccharified and $89 \%$ of the lignin was retained with the digested solids. Therefore, $1 \mathrm{~kg}$ of processed switchgrass MPV3 produces $227 \mathrm{~g}$ of glucan and $118 \mathrm{~g}$ of xylan for fermentation.

\section{Comparison of switchgrass samples for sugar and ethanol yields}

The developed protocol was applied to all of the switchgrass samples. Following pretreatment, all the samples were analysed for composition (Table 1, bottom half). Recoveries of glucan and xylan were $98.4-102.9 \%$. The values that exceed $100 \%$ indicate either evaporation of volatile compounds or measurement error. Either way, the results demonstrate that ammonia pretreatment does not decompose carbohydrates in contrast to acid catalysed pretreatments.[30]

The pretreated switchgrass sample set was treated with enzymes under the same conditions finalized in the pretreatment optimization experiments. The glucose and xylose hydrolysis efficiencies were $66.9-90.5 \%$ and $60.1-84.2 \%$ of maximum, respectively (Figure 6(a)). Switchgrass MPV1 was the least resistant to conversion and MPV3 was the most recalcitrant for the pretreatment conditions studied. Recalcitrance to enzymatic conversion increased with harvest maturity. Glucose and xylose sugar yields were 254 $299 \mathrm{~g} / \mathrm{kg}$ switchgrass, db, and 173-194 g/kg switchgrass, $\mathrm{db}$, respectively (Figure $6(\mathrm{~b}))$. Sugar yields $(\mathrm{g} / \mathrm{kg}$ ) were more consistent than efficiencies [percentage of theoretical] because switchgrass plants harvested at a younger maturity were less recalcitrant to enzyme digestion but poorer in carbohydrate content compared with older maturity plants.

Ethanol yields do not always correlate closely with enzyme sugar yields because SSFs are typically conducted at higher solids, which also concentrate inhibitors of enzymes and microbes. Therefore, pretreated switchgrass samples were processed to ethanol using an SSF scheme using the aforementioned enzyme cocktail and 

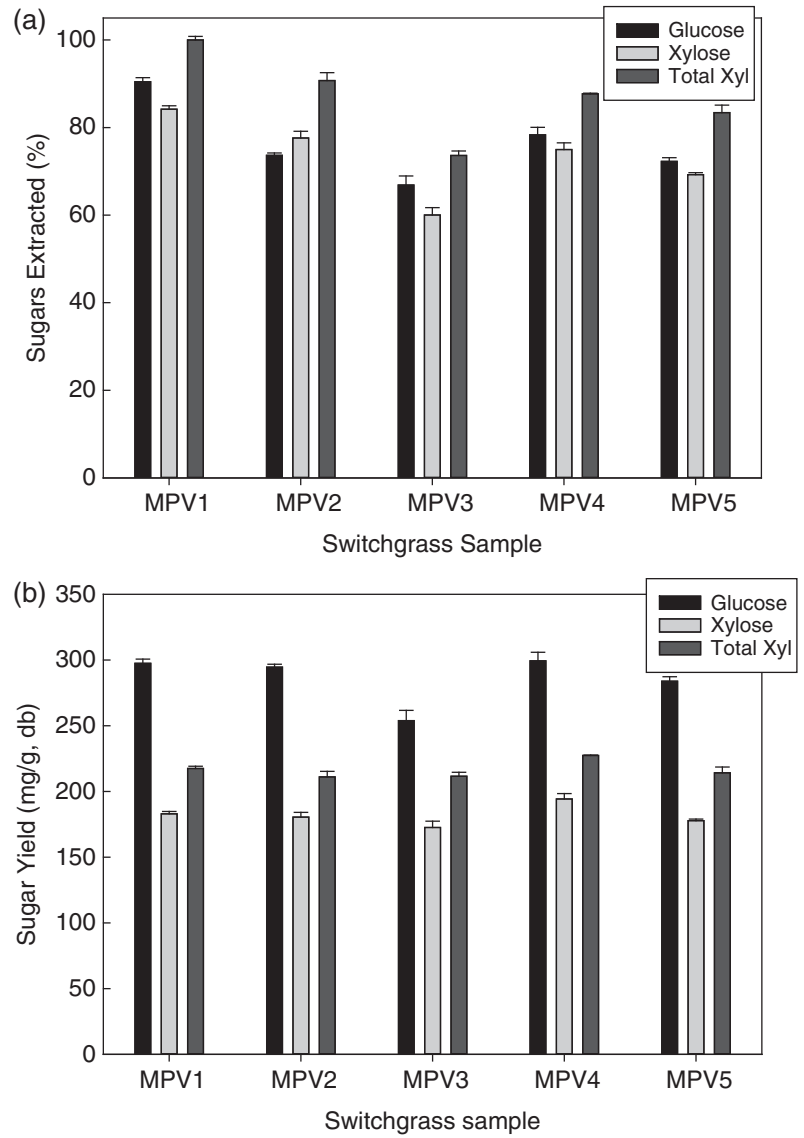

Figure 6. Comparison of percentage extracted carbohydrates (a) and yields (b) for ammonium pretreated switchgrass MPV1-MPV5 following enzymatic hydrolysis. Samples were analysed for glucose, xylose, and soluble xylan/xylose.

yeast YRH400 (Table 3). The final ethanol concentrations for the $10 \%$ biomass loading were $12.9-14.9 \mathrm{~g} / 1$. All of the glucose was consumed but most of the xylose remained (6.98-9.315 g/l) and most of the xylose that was consumed was converted to xylitol $(4.47-5.87 \mathrm{~g} / 1)$. For this reason, the ethanol yield efficiencies (percentage of max) were calculated on a glucose only and glucose + xylose basis (Table 3 and Figure 7). The conversions on a glucose only basis are encouraging $(72.0-93.7 \%$ of max $)$ but much lower

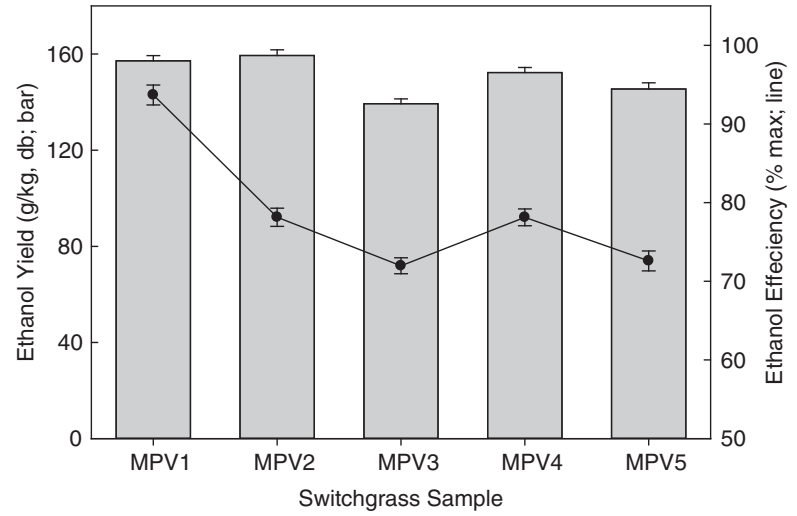

Figure 7. Comparison of ethanol yields (bars) and conversion efficiencies (line) for ammonia-pretreated switchgrass samples MPV1-MPV5 after SSF. Cultures were sampled at $72 \mathrm{~h}$ for glucose, xylose, and soluble xylan/xylose (xylan + xylose).

when xylose is included (41.0-56.4\%). This contrast in efficiencies highlights the importance of continued strain improvement for xylose-fermenting S. cerevisiae. Perhaps, however, the most meaningful statistic is the ethanol yield on a beginning biomass basis ( $\mathrm{g} / \mathrm{kg}$ switchgrass, $\mathrm{db}$; Table 3 and Figure 7). The ethanol yields were surprisingly consistent among the switchgrass samples given the difference in theoretical ethanol yields, which were calculated from carbohydrate compositions (Table 1). In particular, it was observed that for switchgrass MPV1, the lower sugar contents were compensated by increased conversion efficiencies compared with the other samples. This result would support efforts to develop switchgrass for increased conversion efficiencies. One encouraging aspect of these results is that all of the switchgrass samples other than MPV1 had similar conversion efficiencies, despite differing in type and harvest maturity, thus demonstrating the robustness of the developed process.

\section{Discussion}

Switchgrass is currently being developed as an industrial feedstock for cellulosic ethanol production.[35] Two basic management decisions are which variety to plant and when

Table 3. Comparison of fermentation results for SSF of ammonia-pretreated switchgrass samples MPV1-MPV5. Fermentations were halted after $96 \mathrm{~h}$.

\begin{tabular}{|c|c|c|c|c|c|c|c|c|c|}
\hline Switchgrass & $\begin{array}{l}\text { Xylose } \\
(\mathrm{g} / \mathrm{l})\end{array}$ & $\begin{array}{l}\text { Arabinose } \\
(\mathrm{g} / \mathrm{l})\end{array}$ & $\begin{array}{c}\text { Xylitol } \\
(\mathrm{g} / \mathrm{l})\end{array}$ & $\begin{array}{l}\text { Glycerol } \\
(\mathrm{g} / \mathrm{l})\end{array}$ & $\begin{array}{c}\text { Acetate } \\
(\mathrm{g} / 1)\end{array}$ & $\begin{array}{c}\text { Ethanol } \\
(\mathrm{g} / \mathrm{l})\end{array}$ & $\begin{array}{l}\text { Eff. Glua } \\
(\% \max )\end{array}$ & $\begin{array}{l}\text { Eff. } X+G^{b} \\
(\% \max )\end{array}$ & $\begin{array}{c}\text { Ethanol yield } \\
(\mathrm{g} / \mathrm{kg}, \mathrm{db})\end{array}$ \\
\hline MPV1 & $9.15 \pm 0.03^{\mathrm{c}}$ & $3.44 \pm 0.06$ & $4.97 \pm 0.30$ & $1.58 \pm 0.50$ & $0.75 \pm 0.02$ & $14.5 \pm 0.3$ & $93.7 \pm 1.3$ & $56.4 \pm 0.77$ & $157.2 \pm 2.1$ \\
\hline MPV2 & $9.31 \pm 0.02$ & $3.32 \pm 0.04$ & $4.47 \pm 0.03$ & $1.39 \pm 0.05$ & $0.89 \pm 0.02$ & $14.9 \pm 0.2$ & $78.1 \pm 1.2$ & $49.4 \pm 0.73$ & $159.4 \pm 2.4$ \\
\hline MPV3 & $7.64 \pm 0.03$ & $3.32 \pm 0.07$ & $5.44 \pm 0.16$ & $1.11 \pm 0.04$ & $0.93 \pm 0.07$ & $12.9 \pm 0.4$ & $72.0 \pm 1.0$ & $41.0 \pm 0.58$ & $139.4 \pm 2.0$ \\
\hline MPV4 & $7.42 \pm 0.03$ & $3.22 \pm 0.10$ & $5.87 \pm 0.19$ & $1.15 \pm 0.03$ & $0.68 \pm 0.04$ & $13.8 \pm 0.4$ & $78.1 \pm 1.1$ & $46.6 \pm 0.64$ & $152.3 \pm 2.1$ \\
\hline MPV5 & $6.98 \pm 0.01$ & $3.12 \pm 0.05$ & $5.37 \pm 0.13$ & $1.09 \pm 0.02$ & $0.84 \pm 0.03$ & $13.2 \pm 0.3$ & $72.6 \pm 1.3$ & $43.9 \pm 0.77$ & $145.5 \pm 2.6$ \\
\hline
\end{tabular}

${ }^{a}$ Effeciency glucose (Eff Glu): \% of theoretical amount of ethanol achieved based upon glucan content of switchgrass.

${ }^{b}$ Effeciency Xylose + Glucose $($ EffX $+\mathrm{G}): \%$ of theoretical amount of ethanol achieved based upon glucan + xylan content of switchgrass.

${ }^{\mathrm{c}}$ Standard deviation of duplicate fermentations. 
to harvest the field. In this study, upland and lowland switchgrass samples were evaluated for ethanol production at different harvest maturities. Carbohydrate contents are critically important when determining the value of a bale of biomass because it directly determines the maximum fermentation yield. A higher glucan to xylan ratio is also preferred because glucose is fermented faster and more efficiently than xylose, albeit both sugars have a theoretical yield of $0.51 \mathrm{~g}$ ethanol per gram sugar.[10] For CIR, the preferred maturities were anthesis and post-frost because the former had higher glucan content and the latter slightly more total carbohydrates (Table 1). For the Kanlow variety, the preference based upon composition would be the postfrost because it had higher glucan and total carbohydrate contents (Table 1).

The compositions reported here can be compared with those in the literature to judge the variability in composition for different switchgrass samples. CIR contents measured here are similar to those listed in the US Department of Energy (DOE) data base (320 and $590 \mathrm{~g} / \mathrm{kg}$ glucans and total carbohydrates, respectively) [14] and reported in a prior study (286-348 g/ $\mathrm{kg}$ glucans and $520-636 \mathrm{~g} / \mathrm{kg}$ total carbohydrates).[36-38] The lowland experimental strain Kanlow N1 composition observed here is higher than the previously reported mean based upon an analysis of over 100 switchgrass samples: $299 \mathrm{~g}$ glucans/ $\mathrm{kg}$ switchgrass and $549 \mathrm{~g}$ total cell wall carbohydrates $/ \mathrm{kg}$,[39] which suggests the samples reported here have higher plant cell carbohydrate contents than those of other reports. However, these switchgrass samples represented a much greater range in harvest maturity, cultivars and experimental strains, and geographical production area. Alamo is another lowland variety that has been selected in previous bioconversion studies. It is listed as having $334.8 \mathrm{~g} / \mathrm{kg}$ of glucans and $261.0 \mathrm{~g} / \mathrm{kg}$ of hemicellulose in the US DOE data base [14] and $320-388 \mathrm{~g} / \mathrm{kg}$ glucans and $580-624 \mathrm{gg} / \mathrm{kg}$ total carbohydrates in prior bioconversion studies.[36,40] While the Kanlow N1 experimental cultivar was observed in this study to have higher carbohydrate contents than those reported previously for switchgrass samples, further evaluation is required for a general conclusion. Composition is influenced by management and environment in addition to genetics. This small survey of compositional values highlights the need to develop a better understanding of the variability in switchgrass carbohydrate composition and to develop tools to allow for fast analysis of carbohydrate contents at the factory gate. We have recently released an near infrared calibration suitable for this purpose.[39]

Biomass is said to be recalcitrant to biochemical conversion because of the inability to extract carbohydrates as sugars at stoichiometric yields.[41] Therefore, sugar and ethanol yields need to be directly determined using standard enzyme and fermentation assays. Both types of conversion begin with a pretreatment step that increases the porosity of the plant cell wall, allowing cellulase to contact the cellulose fibres. In this study, ammonium hydroxide pretreatment was selected for several reasons. Grasses are extremely responsive to alkaline-based pretreatments where the ammonia disrupts the xylan and lignin matrix, increases porosity, removes xylan acetyl groups, and disrupts cellulose structure.[8,9] In particular for grasses, ammonia disrupts ester bonds linking the hemicellulose and lignin. For this reason, ammonia has a long history of being used to improve forage quality.[8] Ammonia can also be removed following pretreatment by evaporation, which dispenses with the need to chemically neutralize the hydrolysate and offers the opportunity for ammonia recycling. Finally, as will be discussed further, the whole hydrolysate is directly fermentable without the need for prior conditioning.

The optimal pretreatment conditions for switchgrass were determined to be $8 \% \mathrm{w} / \mathrm{w}$ ammonia loading at $170^{\circ} \mathrm{C}$ for $20 \mathrm{~min}$ (Figures 1 and 2(a) and 2(b)). Dilute ammonium hydroxide was previously used for conversion of alfalfa (Medicago sativa) stems, reed canarygrass (Phalaris arundinacea), and forage sorghum (Sorghum spp.).[17-19] The conditions reported here are the same used for alfalfa and at twice the chemical loading used for the other grasses, which suggests that switchgrass is more recalcitrant than reed canary grass and forage sorghum. Enzyme formulation is particularly important for alkaline pretreatments because most commercial cellulases do not contain sufficient hemicellulose-related activities to complete xylan hydrolysis to xylose.[34] Supplementing commercial cellulase with pectinase, surfactant, $\beta$-glucosidase, and $\beta$ xylosidase activities improved recoveries of glucose and xylose (Figure 3, data not shown). Earlier reports for enzymatic hydrolysis of ammonia fibre expansion (AFEX) pretreated switchgrass used a similar mixture consisting of commercial cellulase, $\beta$-glucosidase, xylanase, pectinase, and surfactant.[36,42]

Pretreatment of biomass frequently produces a product that microorganisms are incapable of fermenting because of the presence of inhibitory chemicals.[32] The pretreated biomass is either washed or extensively conditioned prior to fermentation, adding to the process costs.[31] In contrast, pretreated MPV3 switchgrass hydrolysate could be directly fermented to ethanol by yeast strains D5A and YRH400 (Figure 4) without any evidence of a prolonged lag phase. Similar results have been observed for dilute ammonium hydroxide pretreated alfalfa stems, reed canary grass, and forage sorghum.[17-19] One major reason that ammonia pretreatment is relatively benign compared with other pretreatments (especially acid catalysed ones) is because carbohydrates are largely preserved. Following ammonia pretreatment of switchgrass, $93 \%$ of the glucan, and $96 \%$ of the xylan were recovered (Table 2 and Figure 5). Comparison of carbohydrate contents for all five switchgrass samples pre- and post-pretreatment revealed minimal carbohydrate losses (Table 1, bottom half). Other pretreatments convert sugars to furans and organic acids that are highly toxic to microorganisms.[30] 
Glucose and ethanol production efficiencies (percentage theoretical) for ammonia-pretreated switchgrass samples showed similar trends. The samples ranked from the least to most recalcitrant for CIR and Kanlow N1 samples are as follows: CIR pre-boot $>$ CIR anthesis $>$ Kanlow N1 anthesis $>$ Kanlow N1 post-frost $>$ CIR postfrost. Glucan efficiencies were $60.1-84.2 \%$ (Figure 6) and ethanol efficiencies were either $72.6-93.7 \%$ (glucan basis) or $43.9-56.4 \%$ (glucan and xylan basis) (Table 3 and Figure 7). Ethanol efficiencies were low because of poor xylose utilization by YRH400 in the presence of glucose. A similar effect was noted earlier for YRH400 [20] and in general for xylose-fermenting yeast strains.[26]

Increased recalcitrance with greater maturity appears to be a consistent trend for switchgrass. When the same CIR samples were subjected to dilute-acid pretreatment (at $121^{\circ} \mathrm{C}$ or $150^{\circ} \mathrm{C}$ ),[24] glucose production efficiencies were also observed to decrease with maturity. Likewise, when AFEX was applied to CIR switchgrass of early and late maturity, the sugar recoveries were $89.0 \%$ and $60.9 \%$, respectively.[36] This appears in part to be a function of increased lignin contents for the more mature plants. For the dilute-acid pretreatment study, it was further observed (for switchgrass and other herbaceous species in the sample set) that Klason lignin increased with plant maturity and that Klason lignin content was inversely correlated to glucose yields $\left(r^{2}=0.82\right)$. [24] In a subsequent study in which $>100$ switchgrass samples were pretreated with diluteacid under low severity conditions $\left(121^{\circ} \mathrm{C}\right)$, neutralized with $\mathrm{Ca}(\mathrm{OH})_{2}$, and subjected to SSF using a non-xylosefermenting $S$. cerevisiae strain, it was observed that conversion of glucan to ethanol was inversely correlated to acid detergent lignin ([39]; personal communication). Finally, when individual switchgrass stems were cut along the internodes and arranged from the newest to oldest segment, ethanol conversion efficiencies were observed to decrease with greater Klason lignin content (data not shown).

There are other factors in addition to Klason lignin contents that play a role in biomass recalcitrance. For example, for early and late harvested Alamo (lowland) switchgrass pretreated with AFEX, sugar production efficiencies were $64.0 \%$ and $68.9 \%$, respectively; the opposite of what was expected.[36] Likewise in this study, glucose production efficiencies for pretreated Kanlow N1 early and late harvested samples were $78.4 \%$ and $72.3 \%$ but the Klason lignin contents were nearly the same (Table 1).

It was also observed in this and the cited AFEX study [36] that the post-frost harvested lowland ecotype switchgrass biomass was less recalcitrant than the post-frost upland biomass. This trend is also supported by a study that compared five pretreatments on enzymatic saccharification of Alamo (lowland) and Shawnee (upland).[11] The pretreatments compared were AFEX, dilute-acid, liquid hot-water, lime, and soak aqueous ammonium. For all pretreatments, the upland switchgrass had greater percentage glucan than the lowland ecotype. This might appear unexpected as upland switchgrass varieties are favoured for their forage properties, but forages are cut at an early maturity. If further substantiated, this has important implications because lowland switchgrass varieties tend to give higher production yields while upland varieties are associated with greater rumen digestibility.[3] If lowland switchgrass cultivars are less recalcitrant than upland ecotypes when cut at later stages, this would argue for the use of lowland varieties for bioenergy production.

There are two ways to increase bioenergy production from a field of switchgrass. They are to increase biomass production and conversion efficiency. Conversion efficiency also brings greater economic benefits as it means that less biomass needs to be shipped to the production facility and less processed (e.g. smaller sized equipment) to yield the same amount of ethanol. As such, conversion efficiencies are a measure of how much can be done by breeding or molecular engineering plants for lowering recalcitrance to enzymatic conversion. The difference for per cent glucose yield between the most and least recalcitrant samples was $18.2 \%$. This suggests that efforts to breed better switchgrass plants [43] or construct low-lignin mutants are worthwhile.[44]

Glucose and ethanol yields [g/kg switchgrass, $\mathrm{db}]$ were much more consistent for the switchgrass set compared with production efficiencies (percentage theoretical) (Figures 6 and 7). Glucose yields were 254-299 g/ $\mathrm{kg}$ and compared favourably with prior results. In the aforementioned AFEX study,[36] except a particularly high glucose yield for early harvested CIR $(321 \mathrm{~g} / \mathrm{kg})$, the glucose yields were generally lower $(210-237 \mathrm{~g} / \mathrm{kg})$. In another survey study [45] that applied the same five pretreatments cited earlier to post-frost harvested Dacotah switchgrass, the glucose yields were $253-335 \mathrm{~g} / \mathrm{kg}$ for enzymatic digestion of washed pretreated samples. The pretreatments evaluated in this study included: AFEX, dilute-acid, lime, liquid hot-water, soaking in aqueous ammonia, and steam explosion with sulphuric dioxide. Washing a sample prior to cellulase treatment is known to increase the extent of cellulose conversion.[29,46]

Ethanol yields were $138-159 \mathrm{~g} / \mathrm{kg}$ switchgrass, $\mathrm{db}$ (Table 3 and Figure 7) and are also similar to prior results. In a similar study, where CIR was pretreated by soaking in dilute ammonia and SSF with a wild-type $S$. cerevisiae strain that only fermented glucose, the ethanol yield efficiency was $73 \%$ of theoretical based upon the glucan content measured after pretreatment.[38] In this study, the ethanol yield efficiencies were $72.0-93.7 \%$ based upon initial glucan content. The ethanol yield using xylose-fermenting Saccharomyces strain 424A (LNH-ST) on AFEX-pretreated switchgrass for $144 \mathrm{~h}$ SSF culture was similar to what is reported here: 165 and $178 \mathrm{~g} / \mathrm{kg}$ switchgrass.[42] One shortcoming for this and the AFEX study, as previously discussed, was the poor performance on xylose, a phenomenon that is common to xylose-fermenting yeast. However, using a clever variation of the SSF culture, the ethanol yield was subsequently increased to $191 \mathrm{~g} / \mathrm{kg}$ 
switchgrass.[42] In this study, xylose was extracted prior to inoculation by pre-adding xylanase and pectinase. The xylose-fermenting yeast was allowed to ferment the xylose for $60 \mathrm{~h}$ prior to adding most of the cellulases. In terms of conversion yield, there is no advantage in using either anthesis or post-frost harvested switchgrass. The choice of switchgrass maturity can be made on the basis of loss in production (post-frost) and added nitrogen requirements (anthesis).

\section{Summary \\ Ammonia pretreatment was shown to be effective to pre- pare switchgrass for biochemical conversion to sugars and ethanol. Notable was the absence of a lag phase for fer- mentation of unconditioned switchgrass hydrolysate. Sugar and ethanol conversion efficiencies decreased with maturity but yields were similar for all the samples. As switch- grass plants mature, increases in carbohydrate contents appear to compensate for greater recalcitrance to conver- sion. Glucose yields were $254-299 \mathrm{~g} / \mathrm{kg}$ and xylose yields $178-194 \mathrm{~g} / \mathrm{kg}$. These represent recoveries of $66.9-90.5 \%$ for total glucans and $60.1-84.2 \%$ for total xylans. Ethanol yields were $139-159 \mathrm{~g} / \mathrm{kg}$ switchgrass, db. Opportunities exist for increasing ethanol yields by lowering recalcitrance for more mature switchgrass plants and improving yeast fermentation of xylose.}

\section{Acknowledgements}

We thank Genencor, Inc. for the generous donation of the enzymes and Victoria Nguyen for excellent technical assistance.

\section{Funding}

This work was supported in part by Agriculture and Food Research Initiative Competitive from the USDA National Institute of Food and Agriculture [grant number 2011 68005-30411].

\section{References}

[1] Bomgardner MM. Building a new biofuels industry. Chem Eng News. 2013;91:20-22.

[2] US Department of Energy. U.S. Billion-Ton Update: Biomass Supply for a Bioenergy and Bioproducts Industry. Perlack RD and Stokes BJ (Leads), ORNL/TM-2011/224. Oak Ridge, TN: Oak Ridge National Laboratory; 2011. p. 227.

[3] Vogel KP, Sarath G, Saathoff AJ, Michell, RB. Switchgrass. In: Halford NGK, Karp A, editors. Energy crops. Cambridge: Royal Society of Chemistry; 2010. p. 341-380.

[4] Lewandowski I, Scurlock JMO, Lindvall E, Christou M. The development and current status of perennial rhizomatous grasses as energy crops in the US and Europe. Biomass Bioenergy. 2003;25:335-361.

[5] Sanderson MA, Adler PR, Boateng AA, Casler MD, Sarath G. Switchgrass as a biofuels feedstock in the USA. Can J Plant Sci. 2006;86:1315-1325.

[6] Schmer MR, Vogel KP, Mitchell RB, Perrin RK. Net energy of cellulosic ethanol from switchgrass. Proc Natl Acad Sci USA. 2008;105:464 469.
[7] Dien BS, Bothast RJ. A primer for lignocellulose biochemical conversion to fuel ethanol. In: Ingledew WM, Kelsall DR, Austin GD, Kluhspies C, editors. The alcohol textbook. Nottingham: Nottingham University Press; 2009. p. 73-93.

[8] Dien BS, Iten LB, Skory CD, Hou C. Converting herbaceous energy crops to bioethanol: a review with emphasis on pretreatment processes. In: Hou CT, editor. Handbook of industrial biocatalysis. Boca Raton, FL: CRC Press, Taylor and Francis Group; 2005. p. 1-11.

[9] Mosier N, Wyman C, Dale B, Elander R, Lee Y, Holtzapple M, Ladisch M. Features of promising technologies for pretreatment of lignocellulosic biomass. Bioresour Technol. 2005;96:673-686.

[10] Dien BS. Mass balances and analytical methods for biomass pretreatment experiments. In: Vertes AA, Qureshi N, Blaschek HP, Yukawa H, editors. Biomass to Biofuels. West Sussex, UK: John Wiley \& Sons, Ltd; 2010. p. 213-231.

[11] Kim Y, Mosier NS, Ladisch MR, Ramesh Pallapolu V, Lee YY, Garlock R, Balan V, Dale BE, Donohoe BS, Vinzant TB, Elander RT, Falls M, Sierra R, Holtzapple MT, Shi J, Ebrik MA, Redmond T, Yang B, Wyman CE, Warner RE. Comparative study on enzymatic digestibility of switchgrass varieties and harvests processed by leading pretreatment technologies. Bioresour Technol. 2011;102: 11089-11096.

[12] Jeffries TW, Jin Y-S. Metabolic engineering for improved fermentation of pentoses by yeasts. Appl Microbiol Biotechnol. 2004;63:495-509.

[13] Vogel KP, Mitchell RB. Heterosis in switchgrass: biomass yield in swards. Crop Sci. 2008;48:2159-2164.

[14] Keshwani DR, Cheng JJ. Switchgrass for bioethanol and other value-added applications: a review. Bioresour Technol. 2009;100:1515-1523.

[15] Tao L, Aden A, Elander RT, Pallapolu VR, Lee YY, Garlock RJ, Balan V, Dale BE, Kim Y, Mosier NS, Ladisch MR, Falls M, Holtzapple MT, Sierra R, Shi J, Ebrik MA, Redmond T, Yang B, Wyman CE, Hames B, Thomas S, Warner RE. Process and technoeconomic analysis of leading pretreatment technologies for lignocellulosic ethanol production using switchgrass. Bioresour Technol. 2011;102:11105-11114.

[16] Wyman CE, Balan V, Dale BE, Elander RT, Falls M, Hames B, Holtzapple MT, Ladisch MR, Lee YY, Mosier N, Pallapolu VR, Shi J, Thomas SR, Warner RE. Comparative data on effects of leading pretreatments and enzyme loadings and formulations on sugar yields from different switchgrass sources. Bioresour Technol. 2011;102:11052-11062.

[17] Dien BS, Casler MD, Hector RE, Iten LB, Nichols NN, Mertens JA, Cotta MA. Biochemical processing of reed canarygrass into fuel ethanol. Int J Low-Carbon Technol. 2012;7:338-347.

[18] Dien BS, Miller DJ, Hector RE, Dixon RA, Chen F, McCaslin M, Reisen P, Sarath G, Cotta, MA. Enhancing alfalfa conversion efficiencies for sugar recovery and ethanol production by altering lignin composition. Bioresour Technol. 2011;102:6479-6486.

[19] Dien BS, Sarath G, Pedersen JF, Sattler SE, Chen H, FunnellHarris DL, Nichols NN, Cotta MA. Improved sugar conversion and ethanol yield for forage sorghum (Sorghum bicolor $L$. Moench) lines with reduced lignin contents. Bioenergy Res. 2009;2:153-164.

[20] Hector RE, Dien BS, Cotta MA, Qureshi N. Engineering industrial Saccharomyces cerevisiae strains for xylose fermentation and comparison for switchgrass conversion. J Ind Microbiol Biotechnol. 2011;38:1193-1202.

[21] Dowe N, McMillan J. SSF experimental protocols - lignocellulosic biomass hydrolysis and fermentation. Laboratory 
analytical procedure (LAP), DOE, editor. Golden, CO: National Renewable Energy Laboratory; 2001. p. 19.

[22] Sluiter A, Hames B, Ruiz R, Scarlata C, Sluiter J, Templeton D, Crocker D. Determination of structural carbohydrates and lignin in biomass. Laboratory analytical procedure, DOE, editor. Golden, CO: National Renewable Energy Laboratory; 2008. p. 16.

[23] Selig M, Weiss N, Ji Y. Enzymatic saccharification of lignocellulosic biomass. Laboratory analytical procedure, DOE, editor. Golden, CO: National Renewable Research Laboratory; 2008. p. 8.

[24] Dien BS, Jung H-JG, Vogel KP, Casler MD, Lamb JF, Iten L, Mitchell RB, Sarath G. Chemical composition and response to dilute-acid pretreatment and enzymatic saccharification of alfalfa, reed canarygrass, and switchgrass. Biomass Bioenergy. 2006;30:880-891.

[25] Dien BS, Nagle N, Hicks KB, Singh V, Moreau RA, Tucker MP, Nichols NN, Johnston DB, Cotta MA, Nguyen Q, Bothast RJ. Fermentation of 'quick fiber' produced from a modified corn-milling process into ethanol and recovery of corn fiber oil. Appl Biochem Biotechnol - Part A Enzyme Eng Biotechnol. 2004;115:937-949.

[26] Almeida JR, Runquist D, Sànchez Nogué V, Lidén G, Gorwa-Grauslund MF. Stress related challenges in pentose fermentation to ethanol by the yeast Saccharomyces cerevisiae. Biotechnol J. 2011;6:286-299.

[27] Yang B, Wyman CE. Effect of xylan and lignin removal by batch and flowthrough pretreatment on the enzymatic digestibility of corn stover cellulose. Biotechnol Bioeng. 2004;86:88-98.

[28] $\mathrm{Wu} \mathrm{J,} \mathrm{Ju} \mathrm{L-K.} \mathrm{Enhancing} \mathrm{enzymatic} \mathrm{saccharification} \mathrm{of}$ waste newsprint by surfactant addition. Biotechnol Prog. 1998; 14:649-652.

[29] Qing Q, Yang B, Wyman CE. Xylooligomers are strong inhibitors of cellulose hydrolysis by enzymes. Bioresour Technol. 2010;101:9624-9630.

[30] Palmqvist E, Hahn-Hägerdal B. Fermentation of lignocellulosic hydrolysates. II: inhibitors and mechanisms of inhibition. Bioresour Technol. 2000;74:25-33.

[31] Palmqvist E, Hahn-Hägerdal B. Fermentation of lignocellulosic hydrolysates. I: inhibition and detoxification. Bioresour Technol. 2000;74:17-24

[32] Nichols NN, Dien BS, Cotta MA. Fermentation of bioenergy crops into ethanol using biological abatement for removal of inhibitors. Bioresour Technol. 2010;101:7545-7550.

[33] Liu Z, Slininger P, Dien B, Berhow M, Kurtzman C, Gorsich S. Adaptive response of yeasts to furfural and 5hydroxymethylfurfural and new chemical evidence for HMF conversion to 2, 5-bis-hydroxymethylfuran. J Ind Microbiol Biotechnol. 2004;31:345-352.

[34] Dien BS, Ximenes EA, O’Bryan PJ, Moniruzzaman M, Li X-L, Balan V, Dale B, Cotta MA. Enzyme characterization for hydrolysis of AFEX and liquid hot-water pretreated distillers' grains and their conversion to ethanol. Bioresour Technol. 2008;99:5216-5225.

[35] Tiller K. Tennessee case study in full-scale development and integration of switchgrass feedstocks with biorefinery operations: genera energy and UT biofuels initiative. Ind Biotechnol. 2011;7:357-364.

[36] Bals B, Rogers C, Jin M, Balan V, Dale B. Evaluation of ammonia fibre expansion (AFEX) pretreatment for enzymatic hydrolysis of switchgrass harvested in different seasons and locations. Biotechnol Biofuels. 2010;3:1-11.

[37] Adler PR, Sanderson MA, Boateng AA, Weimer PJ, Jung H-JG. Biomass yield and biofuel quality of switchgrass harvested in fall or spring. Agronomy J. 2006;98:1518-1525.

[38] Isci A, Himmelsbach J, Strohl J, Pometto A, III, Raman DR, Anex R. Pilot-scale fermentation of aqueousammonia-soaked switchgrass. Appl Biochem Biotechnol. 2009; 157:453-462.

[39] Vogel KP, Dien BS, Jung HG, Casler MD, Masterson SD, Mitchell RB. Quantifying actual and theoretical ethanol yields for switchgrass strains using NIRS analyses. Bioenergy Res. 2011;4:96-110.

[40] Hu Z, Sykes R, Davis MF, Charles Brummer E, Ragauskas AJ. Chemical profiles of switchgrass. Bioresour Technol. 2010;101:3253-3257.

[41] Himmel ME, Ding S-Y, Johnson DK, Adney WS, Nimlos MR, Brady JW, Foust TD. Biomass recalcitrance: engineering plants and enzymes for biofuels production. Science. 2007;315:804-807.

[42] Jin M, Lau MW, Balan V, Dale BE. Two-step SSCF to convert AFEX-treated switchgrass to ethanol using commercial enzymes and Saccharomyces cerevisiae 424A(LNH-ST). Bioresour Technol. 2010;101:8171-8178.

[43] Sarath G, Dien B, Saathoff AJ, Vogel KP, Mitchell RB, Chen $\mathrm{H}$. Ethanol yields and cell wall properties in divergently bred switchgrass genotypes. Bioresour Technol. 2011;102 9579-9585.

[44] Fu C, Mielenz JR, Xiao X, Ge Y, Hamilton CY, Rodriguez M, Chen F, Foston M, Ragauskas A, Bouton J, Dixon RA, Wang $\mathrm{Z}-\mathrm{Y}$. Genetic manipulation of lignin reduces recalcitrance and improves ethanol production from switchgrass. Proc Natl Acad Sci USA. 2011;108:3803-3808.

[45] Garlock RJ, Balan V, Dale BE, Ramesh Pallapolu V, Lee YY, Kim Y, Mosier NS, Ladisch MR, Holtzapple MT, Falls M, Sierra-Ramirez R, Shi J, Ebrik MA, Redmond T, Yang B, Wyman CE, Donohoe BS, Vinzant TB, Elander RT, Hames B, Thomas S, Warner RE. Comparative material balances around pretreatment technologies for the conversion of switchgrass to soluble sugars. Bioresour Technol. 2011;102:11063-11071.

[46] Kim Y, Ximenes E, Mosier NS, Ladisch MR. Soluble inhibitors/deactivators of cellulase enzymes from lignocellulosic biomass. Enzyme Microbial Technol. 2011;48: 408-415. 